\title{
Combined Treatment of Radiotherapy and Immunotherapy for Urological Malignancies: Current Evidence and Clinical Considerations
}

This article was published in the following Dove Press journal: Cancer Management and Research

\author{
Haoran Lei \\ Ming Shi \\ Hang Xu \\ Shengjiang Bai \\ Xingyu Xiong \\ Qiang Wei (D) \\ Lu Yang (D)
}

Department of Urology, West China Hospital, Sichuan University, Chengdu, Sichuan, People's Republic of China
Correspondence: Lu Yang

Department of Urology, West China

Hospital, Sichuan University, Chengdu, 37

Guoxue Alley, Chengdu, Sichuan, 6I004I,

People's Republic of China

Tel +86- 18980606829

Fax +86-028-8542245I

Email wycleflue@I63.com

\begin{abstract}
Although it has always been believed that radiation has immunosuppressive effects, more and more preclinical and clinical trials have shown that the combination of radiotherapy and immunotherapy has a potential synergistic effect to treat cancers including urological malignancies. When radiotherapy is combined with immunotherapy, improved prognosis has been observed in different urinary tumors. However, there is no standard treatment, such as the optimal dose/fractionation and the sequence of immunotherapy and radiotherapy. In this review, we discussed the effects of radiotherapy on the cancer immune system and emphasized the synergy of radiotherapy combined with immunotherapy. Although it has significantly improved the prognosis of tumors, there are still some unresolved questions about how to best use this combination in clinical practice. Ongoing trials will provide further information on the interaction of radiotherapy combined with immunotherapy, and are expected to guide clinical practice and improve clinical outcomes.
\end{abstract}

Keywords: radiotherapy, immunotherapy, urological malignancies, abscopal effect

\section{Introduction}

Radiotherapy has a long history in the treatment of tumor. It has a significant effect in the treatment of unresectable diseases and the prevention of postoperative local recurrence. Historically, it is believed that radiation has immunosuppressive effects. Due to the limitation of treatment planning and radiotherapy technology, larger treatment areas were needed in the past, which led to a significant myelosuppression, thus strengthens the above-mentioned concept. ${ }^{1}$ However, the emergence of advanced radiation therapy planning and delivery has made tremendous changes in the ability to treat tumors. Stereotactic radiosurgery and stereotactic ablation radiotherapy (also known as stereotactic body radiation therapy, SBRT) can provide radiotherapy with millimeter level accuracy and minimize the dose to the surrounding tissue structures. ${ }^{2}$ These advances have greatly reduced the fields of radiotherapy and allowed a higher radiation dose. This essential change needs to re-examine the immunological effects of radiotherapy.

It is widely known that the classical mechanism of radiation-mediated cell death is the irreparable damage of DNA through two primary effects. Under the direct effect, photons destroy DNA and break its double strand, which leads to cell apoptosis. Under the indirect effect, hydroxyl free radicals produced by photon beams mediate DNA damage and subsequent cell death. ${ }^{3}$ However, some studies have indicated that the 


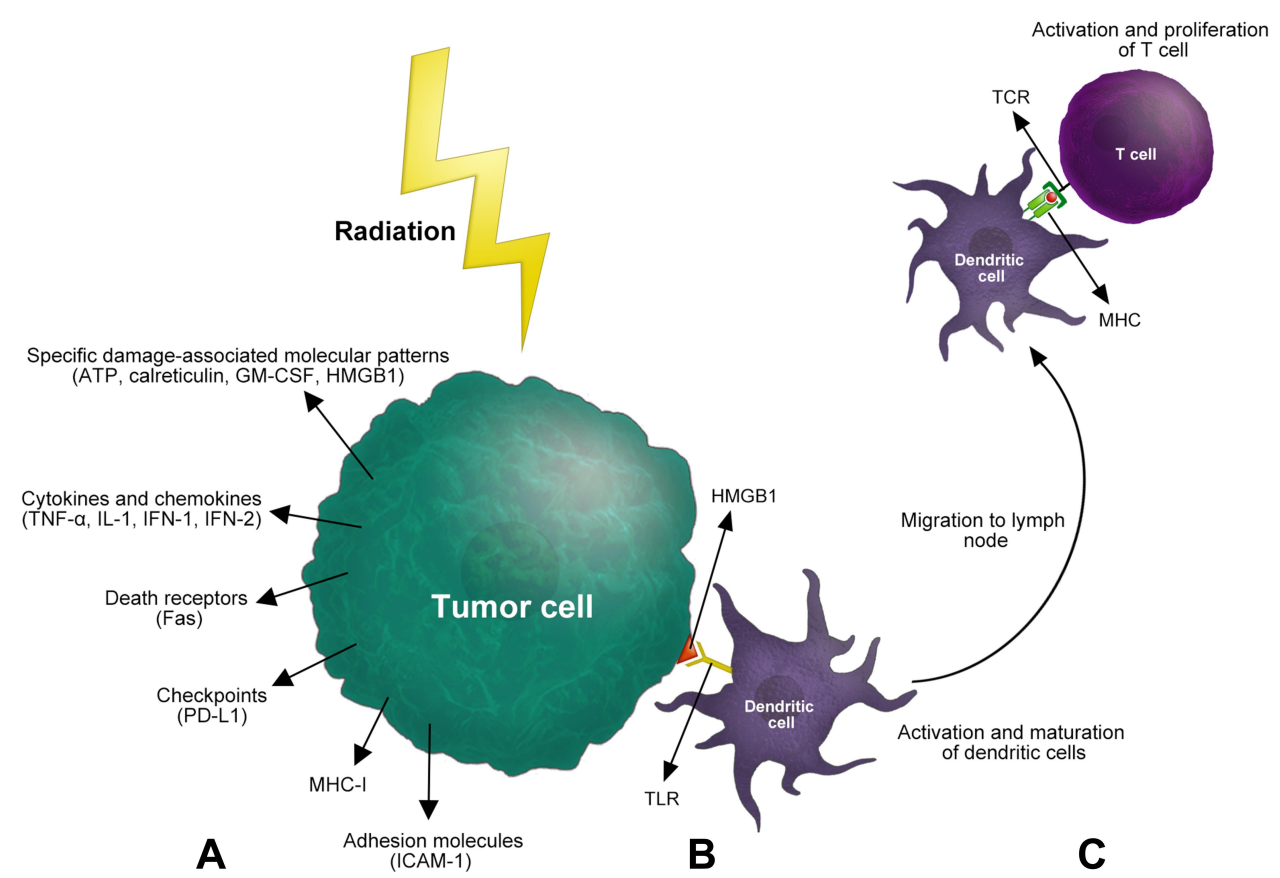

Figure I (A) Radiation induces changes to the tumor cell phenotype and release of cytokines; (B) HMGBI activate dendritic cells by binding to Toll-like receptors; (C) The migration of dendritic cells to regional lymph nodes and the subsequent T-cell activation and proliferation. TLR, Toll-like receptors; TCR, T cell receptor.

immune system plays an important role in radiation therapy by promoting tumor cell death. Stone et $\mathrm{al}^{4}$ reported some of the earliest data on the immune system related to the therapeutic efficacy of radiation. They used different doses of radiation to treat chemically induced fibrosarcoma in mice. The dose of radiation required to control the tumor was significantly reduced when they stimulated the immune system with crude bacterial preparation. Oppositely, when the mice receive immunosuppression before receiving systemic radiotherapy or thymectomy, higher doses of radiation were needed to control tumor growth. ${ }^{4}$ These data indicate that the immune system can affect the therapeutic effects of radiation. In summary, available data suggest that radiotherapy can lead to immunogenic cell death and stimulate systemic antitumor immune response. The immunogenicity of radiotherapy has renewed interest in combining radiotherapy with immunotherapy to further increase systemic antitumor immune responses leading to improved prognosis.

Radiotherapy is used in the clinical treatment for various urological malignancies, such as prostate cancer or bladder cancer. In addition, it can also be used for palliative treatment for bone metastases from urological malignancies to alleviate symptoms. In this review, we discuss the combination of radiotherapy and immunotherapy in urological malignancies and put forward the clinical considerations for future research.

\section{Materials and Methods}

A systematic literature search of PubMed was conducted in May 2020 without language restrictions. Several key terms were used, including "radiation therapy", "radiotherapy", "immunotherapy", "combined" and "combination". The inclusion criteria were treatment included both radiotherapy and immunotherapy combined.

\section{Effects of Radiotherapy on the Tumor Cells}

Radiotherapy causes cell death by irreparable double stranded DNA damage. Despite the belief that radiotherapy is immunosuppressive, radiotherapy has been shown to promote antitumor immune response, although how radiation interacts with the immune system is unclear. ${ }^{5-7}$ There is evidence that radiotherapy can induce the expression of immune factors in tumor cells and tumor microenvironment, and stimulate innate and adaptive immunity resulting in a tumor-specific T-cell response, as well as leukocyte infiltration of tumor in the radiation field. ${ }^{8}$

\section{Immune-Stimulating Effects of Radiation}

Pre-clinical data suggest that radiotherapy has multiple immunogenic effects. The mechanism of radiotherapy leading to immunologic cell death has been explored by numerous reviews. ${ }^{9-12}$ Overall, through the damage of 
tumor cell and regulation of tumor microenvironment, radiotherapy releases specific damage-associated molecular patterns, such as adenosine triphosphate (ATP), calreticulin, granulocyte-macrophage colony-stimulating factor (GM-CSF) and high-mobility group box 1 protein (HMGB1), to induce the activation and maturation of dendritic cells and antigen-presenting cells (APCs). ${ }^{13,14}$ Continuous dendritic cell activation plays an important role in the production of effective antitumor immune response. Radiotherapy has also shown to promote the migration of APCs to regional lymph nodes and the subsequent T-cell priming. ${ }^{15}$ Gameiro et $\mathrm{al}^{16}$ found that radiation can induce a remarkable increase in HMGB1 release and the surface expression of calreticulin in human prostate, breast, and lung cell lines. However, as a damage related molecular pattern, HMGB1 may activate dendritic cells by binding to Toll-like receptors to prime immune responses. $^{17}$

Radiation damage also leads to the release of chemokines, chemokine ligands, CXCL16, which lead to the recruitment of $\mathrm{CD} 8 \mathrm{~T}$-cells in tumor microenvironment and vascular remodeling to maximize the migration of T-cells into tumor. ${ }^{18,19}$ Radiotherapy also induces inflammatory cytokines, including interleukin (IL) $1 \mathrm{~b}$, tumor necrosis factor- $\alpha$ (TNF- $\alpha)$ and type 1 and 2 interferons (IFN-1 and IFN-2), through the STING pathway, to promote the anti-tumor T-cell response. ${ }^{20}$

Radiation damage also leads to the phenotype change of the remaining tumor cells after radiation. For example, the up-regulation of surface molecules, including major histocompatibility complexes (MHC) I, costimulatory T-cell signaling molecules, adhesion molecules (such as intercellular adhesion molecule 1, ICAM-1) and stressinduced ligands, contribute to the recognition and clearance of tumor cells by the immune system. ${ }^{21}$ In addition, radiotherapy can also up-regulate the expression of Fas death receptors on tumor cells and induce the sensitivity of tumor cells to Fas-mediated killing that is unrelated to T-cell receptors. ${ }^{22}$ Garnett et al $^{23}$ found that when delivering radiation to human colon, lung, and prostate cancer cells, the higher the radiation dose, the greater expression of stimulating immune signal and tumor antigen (Fas, MHC-I, ICAM-1, carcinoembryonic antigen [CEA], and mucin) on the surface of tumor cells, which led to more effective immune-mediated tumor killing. Conclusively, all of these effects lead to the formation of proinflammatory microenvironment, anti-tumor activation of the immune system, and increased cancer cell death.

\section{Immune-Suppressive Effects of Radiation}

Interestingly, the effects of radiation on tumor microenvironment and its interaction with the immune system is a complex balance of stimulating and suppressing. In addition to the immune-stimulating effects, radiotherapy can also inhibit the immune response of tumor cells. Radiotherapy has been shown to increase regulatory T-cells (Treg) in the tumor microenvironment, resulting in the inherent higher radiosensitivity of these cells, ${ }^{10}$ the down-regulation of immune response and the secretion of transforming growth factor- $\beta$ (TGF- $\beta$ ). ${ }^{24}$ Kachikwu et al ${ }^{25}$ reported that radiation-promoted tumor regression was enhanced in Treg-deficient prostate cancer model. Besides, radiotherapy can also stimulate myeloid-derived suppressive cells, which support tumor progression by promoting tumor cell survival, angiogenesis, tumor cell invasion and metastasis to healthy tissues. ${ }^{26}$ Recent report by $\mathrm{Wu}$ et al demonstrated that radiotherapy could upregulate programmed death ligand 1 (PD-L1) of bladder cancer mice temporarily. ${ }^{27}$ Similarly, radiotherapy can upregulate the expression of cytotoxic $\mathrm{T}$ lymphocyte antigen4 (CTLA-4) in Treg cells. ${ }^{28}$ In addition, Twyman-Saint Victor et al suggested that radiation enhances the diversity of T-cell receptor repertoire in tumors. After local high dose irradiation, the higher expression of PD-L1 and CTLA-4 was also observed in tumor cells. ${ }^{29}$ Although these are disadvantageous to the immunogenicity of radiotherapy, this provided a strong theoretical basis for the combination of radiotherapy and immune checkpoint blockade, especially in the case of tumor resistant to immunotherapy.

\section{Abscopal Effect}

Radiation-mediated cell death and its effect on tumor microenvironment not only cause local effects, but may also induce "abscopal effect". Abscopal effect refers to the partial or complete remission of distant involved regions outside the radiation field. The term "abscopal effect" was imported by R.H. Mole in 1952 before he introduced drug immunotherapy into oncology. It described radiation effects outside the radiation field but in the same body for the first time. ${ }^{30}$ However, the effect is an ambiguous phenomenon. A systematic review found that in the 35 years from 1969 to 2014, only 46 clinical cases reported the abscopal effect. And most cases were traditionally considered immunogenic, including 7 cases of renal cell carcinoma. ${ }^{31}$ This phenomenon lacks repeatability and its 
mechanism is not clear. However, the combination of radiotherapy and immunotherapy has the potential to impel such abscopal effect repeatable and produce longterm remission for people with metastatic diseases. ${ }^{32}$ Some cases about the abscopal effect with radiotherapy published in the recent literature are based on the treatment of immune checkpoint inhibitor therapy. Park et $\mathrm{al}^{33}$ used preclinical melanoma and renal cell carcinoma models to show the abscopal effect of radiotherapy combined with anti-PD-1 therapy. In addition, Dewan et $\mathrm{al}^{34}$ found that radiotherapy induces the abscopal effect when in combination with anti-CTLA-4 antibody in preclinical breast and colon carcinoma models. This indicates that the combination of radiotherapy and immune checkpoint inhibitor therapy may make the abscopal effect occur more frequently.

\section{Combining Radiotherapy with Immunotherapy}

The term "abscopal effect" and its definition described the non-radiation oncology response caused by the stimulation of the immune system by radiation, which can be supported and intensified by the use of immunologic drugs recently. With the great success of single immunotherapy in the treatment of multiple solid tumors, including melanoma, lung cancer, and urological tumors, it becomes clear that there is an inherently effective immune response without any radiological effects, which can be stimulated by pharmacological stimulation or inhibition of T-cells and/or antigen-presenting cells. However, data from in vitro/ in vivo trials and clinical studies have been accumulating, showing a significant synergy between immunotherapy and radiotherapy. Lee et $\mathrm{al}^{35}$ found that $20-25 \mathrm{~Gy}$ was effective at tumor control in melanoma mice, while it does not work in mice with CD8 T-cells depletion. Thus, there is a hypothesis that enhancing the function of T-cells may lead to radiosensitization and improve local control. Several pre-clinical data supported this hypothesis. ${ }^{27,36}$ However, we must remember that the purpose of animal models is to simplify extremely complex syndromes, usually caused by multiple pathogenies, into manageable research problems. These animal models are in marked contrast to humans with relatively different genetic composition and exposure to a range of environmental stresses. Therefore, animal research results need to be further verified in humans.

\section{Combining Radiotherapy with Immunotherapy in Urological Malignancies}

Some ongoing trials are evaluating the combination of radiotherapy and immunotherapy for urological malignancies. Tables 1-3 describe the clinical trials of patients with prostate cancer, renal cell carcinoma, and urothelial cancer, respectively. The results of these trials are expected to elucidate the potential synergistic effect of radiotherapy and immunotherapy in patients with urological malignancies.

Sipuleucel-T is an active cellular immunotherapy approved by FDA for the treatment of asymptomatic or mild symptoms in patients with metastatic castration-resistant prostate cancer (mCRPC). ${ }^{37}$ Currently, a number of randomized clinical trials (NCT01807065, NCT01818986, NCT02232230, NCT01833208, NCT02463799) are underway to evaluate the efficacy of sipuleucel-T combined with radiotherapy in the treatment of $\mathrm{mCRPC}$.

Recently, with the development of many clinical studies, immune checkpoint inhibitors have received extensive attention. Ipilimumab is the first human monoclonal antibody approved by FDA in the field of cancer. It can specifically block the binding of CTLA-4 and its ligand, thus enhancing the activation and proliferation of $\mathrm{T}$ cells and mediating the anti-tumor effect. ${ }^{38}$ There is a Phase I randomized clinical trial (NCT03477864) determining the safety and tolerability for ipilimumab with SBRT in patients with locally advanced prostate cancer. In addition, pembrolizumab is a humanized antibody, which can block the inhibitory ligand of programmed cell death 1 receptor (PD-1). Several trials (NCT02662062, NCT03419130, NCT02621151, NCT02560636, NCT03287050) investigating the safety, tolerability, and effectiveness of pembrolizumab combined with radiotherapy in muscle-invasive bladder cancer. The study by Twyman-Saint Victor and his colleagues $^{29}$ exploring radiotherapy with dual checkpoint blockage (anti-CTLA-4 and anti-PD-L1 antibodies) in nonurological cancer showed encouraging results. A few ongoing trials (NCT03065179 and NCT03149159) assessing the efficacy of ipilimumab + nivolumab with SBRT in the management of patients with metastatic clear cell renal cell carcinoma.

\section{Clinical Evidence of Combination in Urological Malignancies}

At the ASCO GU in 2020, two studies on SBRT combined with immunotherapy attracted the attention of 
Table I Clinical Trials Combining Immunotherapy with Radiotherapy in Prostate Cancer

\begin{tabular}{|c|c|c|c|c|c|}
\hline Trial & Condition & Aims & Phase & Intervention & Institution/Group \\
\hline NCT0I436968 & $\begin{array}{l}\text { Intermediate- } \\
\text { high risk } \\
\text { localized PCa }\end{array}$ & $\begin{array}{l}\text { The purpose of this study is to evaluate the } \\
\text { effectiveness of ProstAtak immunotherapy in } \\
\text { combination with RT for patients with } \\
\text { intermediate-high risk localized PCa }\end{array}$ & $\begin{array}{l}\text { Phase } \\
\text { III }\end{array}$ & $\begin{array}{c}\mathrm{RT}+\text { valacyclovir } \pm \\
\text { AdV-tK }\end{array}$ & $\begin{array}{l}\text { Advantagene, Inc. d. } \\
\text { b.a. Candel } \\
\text { Therapeutics }\end{array}$ \\
\hline NCT02107430 & $\begin{array}{c}\text { High risk } \\
\text { localized } \mathrm{PCa}\end{array}$ & $\begin{array}{l}\text { To determine whether DCVAC/PCa added after } \\
\text { radical primary prostatectomy can improve PSA } \\
\text { progression times within } 5 \text { years for patients with } \\
\text { high risk localized PCa }\end{array}$ & $\begin{array}{l}\text { Phase } \\
\text { II }\end{array}$ & $\begin{array}{l}\text { RT } \pm \text { dendritic cells } \\
\quad(\mathrm{DCVAC} / \mathrm{PCa})\end{array}$ & $\begin{array}{l}\text { Sotio a.s. (Czech } \\
\text { Republic) }\end{array}$ \\
\hline NCT0I807065 & $\mathrm{mCRPC}$ & $\begin{array}{l}\text { To study how well giving sipuleucel-T with or } \\
\text { without RT works in treating patients with mCRPC }\end{array}$ & $\begin{array}{l}\text { Phase } \\
\text { II }\end{array}$ & $\begin{array}{l}\text { RT followed by } \\
\text { sipuleucel-T }\end{array}$ & $\begin{array}{l}\text { City of Hope } \\
\text { Medical Center }\end{array}$ \\
\hline NCT0I8I8986 & $\mathrm{mCRPC}$ & Sipuleucel-T and SABR for patients with mCRPC & $\begin{array}{l}\text { Phase } \\
\text { II }\end{array}$ & SABR + sipuleucel-T & $\begin{array}{l}\text { University of Texas } \\
\text { Southwestern } \\
\text { Medical Center }\end{array}$ \\
\hline NCTOI303705 & Metastatic PCa & $\begin{array}{l}\text { To examine a novel combination of anti-OX } 40 \text { to } \\
\text { induce proliferation of memory and effector T-cells } \\
\text { in conjunction with cyclophosphamide }(\mathrm{CTX}) \text { and } \\
\text { radiation to induce tumour antigen release with the } \\
\text { overall goal of promoting an immune response } \\
\text { against prostate cancer }\end{array}$ & $\begin{array}{l}\text { Phase } \\
\text { I/II }\end{array}$ & $\begin{array}{c}\mathrm{RT}+ \\
\text { cyclophosphamide }+ \\
\text { anti-OX40 }\end{array}$ & $\begin{array}{l}\text { Providence Portland } \\
\text { Medical Center }\end{array}$ \\
\hline NCT02232230 & mCRPC & $\begin{array}{l}\text { To assess the effect of RT to augment antitumor } \\
\text { responses from immune therapy with Provenge }\end{array}$ & $\begin{array}{l}\text { Phase } \\
\text { II }\end{array}$ & RT + sipuleucel-T & $\begin{array}{l}2 \text { Ist Century } \\
\text { Oncology }\end{array}$ \\
\hline NCT03477864 & $\begin{array}{l}\text { Locally } \\
\text { advanced } \\
\text { prostate cancer }\end{array}$ & $\begin{array}{l}\text { To study the side effects of anti-PD-I monoclonal } \\
\text { antibody REGN28I0 and/or ipilimumab when given } \\
\text { together with SBRT before surgery in treating } \\
\text { participants with progressive advanced or } \\
\text { oligometastatic PCa }\end{array}$ & $\begin{array}{l}\text { Phase } \\
\text { I }\end{array}$ & $\begin{array}{l}\text { SBRT + anti-PD-I } \pm \\
\text { ipilimumab before } \\
\text { radical } \\
\text { prostatectomy }\end{array}$ & $\begin{array}{l}\text { Sidney Kimmel } \\
\text { Cancer Center at } \\
\text { Thomas Jefferson } \\
\text { University }\end{array}$ \\
\hline NCT03007732 & $\begin{array}{l}\text { Hormone-naïve } \\
\text { oligometastatic } \\
\text { PCa }\end{array}$ & $\begin{array}{l}\text { SBRT and pembrolizumab with or without } \\
\text { intratumoral SD-I0I in patients with newly } \\
\text { diagnosed hormone-naive oligometastatic PCa }\end{array}$ & $\begin{array}{l}\text { Phase } \\
\text { II }\end{array}$ & $\begin{array}{c}\text { SBRT + ADT + } \\
\text { pembrolizumab } \pm \\
\text { TLR9 agonist (SD- } \\
\text { I0I) }\end{array}$ & $\begin{array}{l}\text { Lawrence Fong, } \\
\text { University of } \\
\text { California }\end{array}$ \\
\hline NCT0I833208 & mCRPC & $\begin{array}{l}\text { Impact of radiation therapy on the immunogenicity } \\
\text { of sipuleucel-T }\end{array}$ & $\begin{array}{l}\text { Pilot } \\
\text { study }\end{array}$ & RT + sipuleucel-T & $\begin{array}{l}\text { Roswell Park Cancer } \\
\text { Institute }\end{array}$ \\
\hline NCT02463799 & $\mathrm{mCRPC}$ & $\begin{array}{l}\text { To study the effect of radium- } 223 \text { when added to } \\
\text { sipuleucel-T for treating castrate-resistant prostate } \\
\text { cancer that has spread to the bone }\end{array}$ & $\begin{array}{l}\text { Phase } \\
\text { II }\end{array}$ & $\begin{array}{c}\text { Radium-223 + } \\
\text { sipuleucel-T }\end{array}$ & $\begin{array}{l}\text { Sidney Kimmel } \\
\text { Comprehensive } \\
\text { Cancer Center at } \\
\text { Johns Hopkins }\end{array}$ \\
\hline
\end{tabular}

Abbreviations: $\mathrm{PCa}$, prostate cancer; $\mathrm{mCRPC}$, metastatic castrate-resistant prostate cancer; RT, radiation therapy; PSA, prostate-specific antigen; SABR, stereotactic ablative radiosurgery; SBRT, stereotactic body radiation therapy; Anti-PD-I, antibody against programmed cell death protein I; ADT, androgen deprivation therapy; AdV-tK, adenoviral vector expressing the herpes thymidine kinase gene; TLR9, toll-like receptor 9 .

participants. NIVES is a Phase II multicenter study $(\mathrm{NCT} 03469713)^{47}$ in Italy, which explored the safety and efficacy of nivolumab combined with radiotherapy for metastatic renal cell carcinoma (mRCC) after failure of targeted therapy. Besides, this is the first prospective clinical study of nivolumab combined with radiotherapy in the treatment of mRCC. Nivolumab was given as flat dose of $240 \mathrm{mg}$ in intravenous infusion beginning on day 1 every 14 days for 6 months, and SBRT (30 Gy/3 fractions) was administered 7 days after the first infusion 
Table 2 Clinical Trials Combining Immunotherapy with Radiotherapy in Renal Cell Carcinoma

\begin{tabular}{|c|c|c|c|c|c|}
\hline Trial & Condition & Aims & Phase & Intervention & $\begin{array}{l}\text { Institution/ } \\
\text { Group }\end{array}$ \\
\hline NCT0I89627I & Metastatic ccRCC & $\begin{array}{l}\text { To evaluate the RR in patients with } \mathrm{mRCC} \\
\text { after treatment with high-dose IL-2 } \\
\text { immediately following SABR to multiple } \\
\text { metastatic sites }\end{array}$ & $\begin{array}{l}\text { Phase } \\
\text { II }\end{array}$ & $\begin{array}{c}\text { SABR + high-dose } \\
\text { IL-2 }\end{array}$ & $\begin{array}{l}\text { University of } \\
\text { Texas, } \\
\text { Southwestern }\end{array}$ \\
\hline NCT03065I79 & Metastatic ccRCC & $\begin{array}{l}\text { To determine whether the combination of } \\
\text { nivolumab plus ipilimumab and SBRT yields } \\
\text { a clinically compelling antitumor activity } \\
\text { measured as ORR }\end{array}$ & $\begin{array}{l}\text { Phase } \\
\text { II }\end{array}$ & $\begin{array}{l}\text { SBRT + nivolumab } \\
\quad+\text { ipilimumab }\end{array}$ & $\begin{array}{l}\text { University of } \\
\text { Texas, } \\
\text { Southwestern }\end{array}$ \\
\hline NCT02306954 & $\operatorname{ccRCC}$ & $\begin{array}{l}\text { To compare the RR among renal cell cancer } \\
\text { (RCC) patients of high dose IL- } 2 \text { to SBRT + } \\
\text { IL-2 in patients with metastatic renal cancer }\end{array}$ & $\begin{array}{l}\text { Phase } \\
\text { II }\end{array}$ & $\begin{array}{c}\text { SBRT + high-dose } \\
\text { IL-2 }\end{array}$ & $\begin{array}{l}\text { Providence } \\
\text { Health }\end{array}$ \\
\hline NCT0278I506 & Metastatic ccRCC & $\begin{array}{l}\text { To increase the RR of treatment with } \\
\text { Nivolumab by the concurrent } \\
\text { administration of SABR }\end{array}$ & $\begin{array}{l}\text { Phase } \\
\text { II }\end{array}$ & SABR + nivolumab & $\begin{array}{l}\text { University of } \\
\text { Texas, } \\
\text { Southwestern }\end{array}$ \\
\hline NCT0I88496I & $\begin{array}{l}\text { Metastatic RCC or } \\
\text { melanoma }\end{array}$ & $\begin{array}{l}\text { Radiotherapy as an immunological booster } \\
\text { in patients with metastatic melanoma or } \\
\text { renal cell carcinoma treated with high-dose } \\
\text { IL-2 }\end{array}$ & $\begin{array}{l}\text { Phase } \\
\text { II }\end{array}$ & $\begin{array}{l}\text { RT boost + high- } \\
\text { dose IL-2 }\end{array}$ & $\begin{array}{l}\text { Istituto } \\
\text { Scientifico } \\
\text { Romagnolo } \\
\text { (Italy) }\end{array}$ \\
\hline NCT02855203 & Metastatic ccRCC & $\begin{array}{l}\text { To examine the safety, efficacy and biological } \\
\text { effects of combining pembrolizumab (MK- } \\
3475 \text { ) an antibody targeted against anti-(PD- } \\
\text { I), with SABR for oligometastatic RCC }\end{array}$ & $\begin{array}{l}\text { Phase } \\
\text { I/II }\end{array}$ & $\begin{array}{c}\text { SABR + } \\
\text { pembrolizumab }\end{array}$ & $\begin{array}{c}\text { Peter } \\
\text { MacCallum } \\
\text { Cancer Centre } \\
\text { (Australia) }\end{array}$ \\
\hline NCT03050060 & $\begin{array}{c}\text { Metastatic RCC, melanoma, } \\
\text { or NSCLC }\end{array}$ & $\begin{array}{l}\text { To study how well image guided } \\
\text { hypofractionated radiation therapy works } \\
\text { with nelfinavir mesylate, pembrolizumab, } \\
\text { nivolumab, and atezolizumab in treating } \\
\text { patients with metastatic RCC, melanoma, or } \\
\text { NSCLC }\end{array}$ & $\begin{array}{l}\text { Phase } \\
\text { II }\end{array}$ & $\begin{array}{l}\text { IGRT + nelfinavir + } \\
\text { (pembrolizumab or } \\
\text { nivolumab or } \\
\text { atezolizumab) }\end{array}$ & $\begin{array}{l}\text { University of } \\
\text { Washington }\end{array}$ \\
\hline NCT023 I877| & $\begin{array}{l}\text { Recurrent/metastatic H\&N, } \\
\text { RCC, melanoma, or lung } \\
\text { cancer }\end{array}$ & $\begin{array}{l}\text { To study RT and pembrolizumab (MK-3475) } \\
\text { in treating patients with head and neck } \\
\text { cancer, RCC, melanoma, or lung cancer that } \\
\text { has returned, has spread to other parts of } \\
\text { the body, or cannot be removed by surgery }\end{array}$ & $\begin{array}{l}\text { Phase } \\
\text { I }\end{array}$ & $\begin{array}{c}\mathrm{RT}+ \\
\text { pembrolizumab }\end{array}$ & $\begin{array}{l}\text { Thomas } \\
\text { Jefferson } \\
\text { University }\end{array}$ \\
\hline NCT02599779 & Metastatic RCC & $\begin{array}{l}\text { To investigate if a treatment strategy where } \\
\text { SBRT is given with pembrolizumab is } \\
\text { sufficiently active to warrant further } \\
\text { investigation in randomized phase II or III } \\
\text { studies }\end{array}$ & $\begin{array}{l}\text { Phase } \\
\text { II }\end{array}$ & $\begin{array}{c}\text { SBRT + } \\
\text { pembrolizumab }\end{array}$ & $\begin{array}{c}\text { Sunnybrook } \\
\text { Health Sciences } \\
\text { Centre }\end{array}$ \\
\hline NCT03I49I59 & Metastatic ccRCC & $\begin{array}{l}\text { To see if continued nivolumab with the } \\
\text { addition of ipilimumab plus hypo- } \\
\text { fractionated SBRT of a single lesion results in } \\
\text { partial or complete responses in patients } \\
\text { with metastatic ccRCC who fail initial } \\
\text { treatment with single agent nivolumab }\end{array}$ & $\begin{array}{l}\text { Phase } \\
\text { II }\end{array}$ & $\begin{array}{l}\text { SBRT + nivolumab } \\
\quad+\text { ipilimumab }\end{array}$ & $\begin{array}{c}\text { Medical } \\
\text { University of } \\
\text { South Carolina }\end{array}$ \\
\hline
\end{tabular}

(Continued) 
Table 2 (Continued).

\begin{tabular}{|c|c|c|c|c|c|}
\hline Trial & Condition & Aims & Phase & Intervention & $\begin{array}{l}\text { Institution/ } \\
\text { Group }\end{array}$ \\
\hline NCT03II580I & Metastatic RCC or UC & $\begin{array}{l}\text { To examine the overall response rates of } \\
\text { combining immunotherapy (nivolumab/ } \\
\text { atezolizumab) with RT for metastatic RCC } \\
\text { or UC }\end{array}$ & $\begin{array}{l}\text { Phase } \\
\text { II }\end{array}$ & $\begin{array}{c}\text { Nivolumab }+ \\
\text { atezolizumab } \pm \text { RT }\end{array}$ & $\begin{array}{l}\text { Weill Medical } \\
\text { College of } \\
\text { Cornell } \\
\text { University }\end{array}$ \\
\hline NCT028646I5 & Metastatic RCC & $\begin{array}{l}\text { To evaluate safety and preliminary efficacy of } \\
\text { stereotactic body radiation therapy in } \\
\text { patients with metastatic renal cell carcinoma } \\
\text { treated with VEGFR, mTOR or immune } \\
\text { checkpoint inhibitors }\end{array}$ & $\begin{array}{l}\text { Phase } \\
\text { Ib }\end{array}$ & $\begin{array}{l}\text { SBRT + (VEGFR } \\
\text { inhibitor or mTOR } \\
\text { inhibitor or } \\
\text { checkpoint } \\
\text { inhibitor) }\end{array}$ & $\begin{array}{l}\text { Kidney Cancer } \\
\text { Research } \\
\text { Bureau }\end{array}$ \\
\hline NCT034697I3 & Metastatic RCC & $\begin{array}{l}\text { Combining SBRT with nivolumab in patients } \\
\text { with metastatic RCC }\end{array}$ & $\begin{array}{l}\text { Phase } \\
\text { II }\end{array}$ & SBRT + nivolumab & $\begin{array}{c}\text { Gruppo } \\
\text { Oncologico } \\
\text { Italiano di } \\
\text { Ricerca Clinica } \\
\text { (Italy) }\end{array}$ \\
\hline NCT03474497 & $\begin{array}{l}\text { Metastatic NSCLC, RCC, or } \\
\text { HNSCC after failed PD-I/ } \\
\text { PD-LI therapy }\end{array}$ & $\begin{array}{l}\text { To evaluate the safety and toxicity of } \\
\text { pembrolizumab and intralesional IL- } 2 \text { in } \\
\text { combination with hypofractionated } \\
\text { radiotherapy in patients with metastatic } \\
\text { NSCLC, RCC, or HNSCC after failed PD-I/ } \\
\text { PD-LI therapy }\end{array}$ & $\begin{array}{l}\text { Phase } \\
\text { I/II }\end{array}$ & $\begin{array}{c}\text { RT + IL-2 + } \\
\text { pembrolizumab }\end{array}$ & $\begin{array}{l}\text { University of } \\
\text { California, Davis }\end{array}$ \\
\hline NCT035II39I & $\begin{array}{l}\text { NSCLC, UC, melanoma, } \\
\text { RCC, H\&N or HNSCC } \\
\text { cancer }\end{array}$ & $\begin{array}{l}\text { To investigate whether the addition of SBRT } \\
\text { to checkpoint inhibitor treatment in } \\
\text { patients with NSCLC, UCC, melanoma, } \\
\text { RCC, H\&N or HNSCC cancer can improve } \\
\text { progression-free survival as compared to } \\
\text { checkpoint inhibitor monotherapy. }\end{array}$ & $\begin{array}{l}\text { Phase } \\
\text { II }\end{array}$ & $\begin{array}{c}\text { SBRT } \pm \\
\text { (pembrolizumab or } \\
\text { nivolumab) }\end{array}$ & $\begin{array}{c}\text { University } \\
\text { Hospital, Ghent } \\
\text { (Belgium) }\end{array}$ \\
\hline NCT03226236 & Metastatic RCC & $\begin{array}{l}\text { To evaluate the ORR in patients with } \mathrm{mRCC} \\
\text { after treatment with IL-2+dendritic cell } \\
\text { vaccine following RT }\end{array}$ & $\begin{array}{l}\text { Phase } \\
\text { II }\end{array}$ & $\begin{array}{c}\mathrm{RT}+\mathrm{IL}-2+ \\
\text { dendritic cell } \\
\text { vaccine }\end{array}$ & $\begin{array}{l}\text { UO } \\
\text { Immunoterapia } \\
\text { e Laboratorio } \\
\text { TCS, IRCCS } \\
\text { IRST (Italy) }\end{array}$ \\
\hline NCT036930I4 & $\begin{array}{l}\text { Metastatic cancer, melanoma } \\
\text { cancer, lung cancer, bladder } \\
\text { cancer, renal cancer, head/ } \\
\text { neck cancers }\end{array}$ & $\begin{array}{l}\text { Combining SBRT with checkpoint inhibitors } \\
\text { in patients with solid tumors }\end{array}$ & $\begin{array}{l}\text { Phase } \\
\text { II }\end{array}$ & $\begin{array}{c}\text { SBRT+ } \\
\text { (ipilimumab, } \\
\text { nivolumab, } \\
\text { pembrolizumab or } \\
\text { atezolizumab) }\end{array}$ & $\begin{array}{l}\text { Memorial Sloan } \\
\text { Kettering } \\
\text { Cancer Center }\end{array}$ \\
\hline
\end{tabular}

Abbreviations: ccRCC, clear cell renal cell carcinoma; NSCLC, non-small cell lung carcinoma; H\&N, head and neck; UC, urothelial carcinoma; HNSCC, head and neck squamous cell carcinoma; SABR, stereotactic ablative radiosurgery; SBRT, stereotactic body radiation therapy; RT, radiation therapy; IL-2, interleukin-2; mTOR, mammalian target of rapamycin; VEGFR, vascular endothelial growth factor receptor; RR, response rate; ORR, objective response rate.

of nivolumab. A total of 69 patients were enrolled, of which 2 failed to undergo radiotherapy and 4 did not complete the first cycle of treatment, that is, 69 patients in intention-to-treat (ITT) group and 63 patients in perprotocol (PP) group. Among them, clear cell carcinoma accounts for about $80 \%$, and the proportion of lung metastases is more exposed, accounting for $37.7 \%$. In terms of efficacy, after a median follow-up of 15 months, the objective response rate (ORR) of the ITT group and the PP group were $17.4 \%$ and $19 \%$, and the tumor control 
Table 3 Clinical Trials Combining Immunotherapy with Radiotherapy in Urothelial Carcinoma

\begin{tabular}{|c|c|c|c|c|c|}
\hline Trial & Condition & Aims & Phase & Intervention & Institution/Group \\
\hline NCT0289II6I & UC of bladder & $\begin{array}{l}\text { To evaluate the safety and } \\
\text { efficacy of combining } \\
\text { durvalumab with RT followed } \\
\text { by adjuvant durvalumab for } \\
\text { patients with UC of bladder }\end{array}$ & $\begin{array}{l}\text { Phase } \\
\text { lb/ll }\end{array}$ & RT + durvalumab & $\begin{array}{c}\text { Big Ten Cancer Research } \\
\text { Consortium }\end{array}$ \\
\hline NCT033I7I58 & NMIBC & $\begin{array}{l}\text { To establish the safety of } \\
\text { durvalumab monotherapy and } \\
\text { durvalumab in combination } \\
\text { with BCG and EBRT in } \\
\text { NMIBC patients }\end{array}$ & $\begin{array}{c}\text { Phase } \\
\text { I/II }\end{array}$ & $\begin{array}{l}\text { Durvalumab alone, } \\
\text { durvalumab + EBRT, or } \\
\text { durvalumab + BCG }\end{array}$ & $\begin{array}{c}\text { Hoosier Cancer Research } \\
\text { Network }\end{array}$ \\
\hline NCT02662062 & MIBC & $\begin{array}{l}\text { To assess the safety and } \\
\text { feasibility of combining } \\
\text { pembrolizumab with } \\
\text { chemoradiotherapy for } \\
\text { patients with MIBC }\end{array}$ & $\begin{array}{c}\text { Phase } \\
\text { II }\end{array}$ & $\begin{array}{l}\text { RT + cisplatin + } \\
\text { pembrolizumab }\end{array}$ & $\begin{array}{c}\text { Australian and New Zealand } \\
\text { Urogenital and Prostate Cancer } \\
\text { Trials Group }\end{array}$ \\
\hline NCT03I7I025 & MIBC & $\begin{array}{l}\text { To evaluate the rate of failure } \\
\text { free survival at } 2 \text { years after } \\
\text { start of chemoradiation with } \\
\text { adjuvant nivolumab in adult } \\
\text { subjects who undergo } \\
\text { chemoradiation for localized } \\
\text { bladder cancer }\end{array}$ & $\begin{array}{c}\text { Phase } \\
\text { II }\end{array}$ & $\begin{array}{c}\text { Chemoradiation followed by } \\
\text { nivolumab }\end{array}$ & University of Utah \\
\hline NCT034I9I30 & MIBC & $\begin{array}{l}\text { How well radiation therapy } \\
\text { and pembrolizumab work in } \\
\text { treating patients with } \\
\text { urothelial bladder cancer that } \\
\text { is restricted to the site of } \\
\text { origin, without evidence of } \\
\text { spread }\end{array}$ & $\begin{array}{c}\text { Phase } \\
\text { II }\end{array}$ & $\begin{array}{c}\text { Pembrolizumab + } \\
\text { (conventional RT or } \\
\text { hypofractionated RT) }\end{array}$ & University of California \\
\hline NCT0262II5I & MIBC & $\begin{array}{l}\text { To assess the efficacy of } \\
\text { pembrolizumab (MK3475) } \\
\text { added to concurrent radiation } \\
\text { and gemcitabine in the } \\
\text { management of patients with } \\
\text { muscle-invasive urothelial } \\
\text { cancer who are not } \\
\text { candidates for or decline } \\
\text { radical cystectomy }\end{array}$ & $\begin{array}{c}\text { Phase } \\
\text { II }\end{array}$ & $\begin{array}{c}\mathrm{RT}+\text { gemcitabine }+ \\
\text { pembrolizumab }\end{array}$ & NYU Langone Health \\
\hline NCT02560636 & MIBC & $\begin{array}{l}\text { To investigate the safety, } \\
\text { tolerability and effectiveness } \\
\text { of an immunotherapy drug } \\
\text { called pembrolizumab used in } \\
\text { combination with } \\
\text { radiotherapy }\end{array}$ & $\begin{array}{c}\text { Phase } \\
\text { I }\end{array}$ & RT + pembrolizumab & $\begin{array}{c}\text { Royal Marsden NHS Foundation } \\
\text { Trust }\end{array}$ \\
\hline
\end{tabular}

(Continued) 
Table 3 (Continued).

\begin{tabular}{|c|c|c|c|c|c|}
\hline Trial & Condition & Aims & Phase & Intervention & Institution/Group \\
\hline NCT0342I652 & $\begin{array}{l}\text { MIBC ineligible } \\
\text { for } \\
\text { chemotherapy }\end{array}$ & $\begin{array}{l}\text { How well nivolumab works } \\
\text { with radiation therapy in } \\
\text { treating patients with } \\
\text { urothelial bladder cancer that } \\
\text { has spread from its original } \\
\text { site of growth to nearby } \\
\text { tissues or lymph nodes and } \\
\text { are ineligible for } \\
\text { chemotherapy }\end{array}$ & $\begin{array}{l}\text { Phase } \\
\text { II }\end{array}$ & RT + nivolumab & $\begin{array}{c}\text { Barbara Ann Karmanos Cancer } \\
\text { Institute }\end{array}$ \\
\hline NCT03287050 & Metastatic UC & $\begin{array}{l}\text { To investigate the feasibility of } \\
\text { anti-PDLI/PDI } \\
\text { (pembrolizumab) and SBRT in } \\
\text { patients with advanced, } \\
\text { platinum-refractory urothelial } \\
\text { carcinoma }\end{array}$ & $\begin{array}{l}\text { Phase } \\
\text { I }\end{array}$ & SBRT + pembrolizumab & $\begin{array}{l}\text { University of Michigan Rogel } \\
\text { Cancer Center }\end{array}$ \\
\hline NCT03529890 & $\begin{array}{l}\text { Locally } \\
\text { advanced UC } \\
\text { of bladder }\end{array}$ & $\begin{array}{l}\text { To assess safety and efficacy } \\
\text { of preoperative RT before } \\
\text { radical cystectomy combined } \\
\text { with immunotherapy in locally } \\
\text { advanced urothelial } \\
\text { carcinoma of the bladder }\end{array}$ & $\begin{array}{l}\text { Phase } \\
\text { II }\end{array}$ & $\begin{array}{l}\mathrm{RT}+\text { nivolumab followed by } \\
\text { radical cystectomy }\end{array}$ & $\begin{array}{l}\text { Technische Universität München } \\
\text { (Germany) }\end{array}$ \\
\hline NCT03II580I & $\begin{array}{l}\text { Metastatic UC } \\
\text { or RCC }\end{array}$ & $\begin{array}{l}\text { To examine the overall } \\
\text { response rates of combining } \\
\text { immunotherapy with RT for } \\
\text { mUC or RCC }\end{array}$ & $\begin{array}{l}\text { Phase } \\
\text { II }\end{array}$ & Atezolizumab $\pm \mathrm{RT}$ & $\begin{array}{c}\text { Weill Medical College of Cornell } \\
\text { University }\end{array}$ \\
\hline
\end{tabular}

Abbreviations: UC, urothelial carcinoma; NMIBC, non-muscle-invasive bladder cancer; MIBC, muscle-invasive bladder cancer; RCC, renal cell carcinoma; RT, radiation therapy; BCG, bacillus Calmette-Guérin vaccine; EBRT, external beam radiation therapy; SBRT, stereotactic body radiation therapy.

rate was $58 \%$ and $63.5 \%$. The median progression-free survival (PFS) of the whole group was 4.1 months, and the 1-year PFS rate was $32.6 \%$; the median overall survival (OS) period was 22.07 months, and the 1-year OS rate was $73.4 \%$. In this study, the ORR indicators of clear cell carcinoma were better than those of non-clear cell carcinoma $(p=0.01)$. This may be due to the different driver mutation genes in non-clear cell carcinoma and clear cell carcinoma, which led to different immunotherapy responses. In terms of safety, severe treatmentrelated toxicities accounted for $24.6 \%$, and all related toxicities were outside the range of radiotherapy, indicating that radiotherapy itself did not seem to increase the therapeutic toxicity. In short, for mRCC that have failed targeted therapy, nivolumab combined with radiotherapy is generally tolerable. Although it did not reach the expected ORR (40\%), the overall tumor control rate and survival rate of combined radiotherapy were high.
Another multi-center study, RADVAX RCC (NCT03065179), ${ }^{48}$ analyzed whether the dual immunotherapy (nivolumab + ipilimumab) combined with radiotherapy could bring a more satisfactory effect against mRCC on the basis of acceptable toxicity. Under the aforementioned mechanism of radiotherapy to activate immunity, CTLA- 4 inhibitors could proliferate T cells, and PD-1 inhibitors could reverse suppressed $\mathrm{T}$ cells. Based on this, the research was divided into two phases: induction phase and maintenance phase. In the induction phase, dual immunotherapy (nivolumab + ipilimumab) was administrated, and radiotherapy $(10 \mathrm{~Gy} \times 5 \mathrm{f}$ in the tumor center, $8 \mathrm{~Gy} \times 5 \mathrm{f}$ around the tumor, qod) started immediately after the first infusion of nivolumab. Subsequently, during the maintenance phase, only nivolumab treatment was performed. A total of 25 patients were enrolled, and $30 \%$ of patients had positive PD-L1 expression. In terms of radiotherapy, $92 \%$ of patients irradiated 
only one lesion, and the median volume of the lesion was $18.7 \mathrm{~cm} 3$. After a median follow-up of 24 months, none of the lesions that received radiotherapy had progressed, and the lung metastases were most significantly reduced. The median PFS of all patients was 8.21 months, and the 1 -year PFS rate was $36 \%$. Compared with the previous study, such a high local control rate is due to the increase in radiotherapy dose and the dual immunotherapy.

Analyzing the NIVES and the RADVAX RCC, the single dose was $10 \mathrm{~Gy}$, while the former only in 3 fractions (biological equivalent dose was $110 \mathrm{~Gy}$ ), and the latter in 5 fractions (biological equivalent dose was $190 \mathrm{~Gy}$ ). Therefore, for the lesions receiving radiotherapy, the latter has a better local control rate than the former (2-year LC: $100 \%$ vs 1-year LC: $82 \%$ ). However, the appropriate dose of radiotherapy and the fractionation remain to be discussed. The number of radiotherapy lesions in NIVES and the RADVAX RCC was almost only one, and the selected tumor volume was too small to achieve full coverage treatment. In addition, the inconsistency between the gene mutation of the primary lesion and the metastasis might cause the antigen released by radiotherapy of a single lesion not suitable for other lesions, which makes it unable to entirely exert the immune effect induced by radiotherapy.

\section{Clinical Considerations of Combining Radiotherapy with Immunotherapy}

Although the combination of radiotherapy and immunotherapy is becoming a promising method, there are many questions about the clinical application of the combination which remain unanswered. The optimal sequence of radiotherapy and immunotherapy, and the optimal immunotherapy agent and its duration need to be further clarified. In addition, details of radiotherapy, such as optimal dose/fractionation, are unclear. Thirdly, it is necessary to clarify the possible acute and late toxicities of combined treatment.

\section{Dose/Fractionation}

So far, a series of techniques and schedules have been used to investigate the combination of radiotherapy and immunotherapy in preclinical studies. However, the optimal dose/ fractionation of radiation to induce the optimal immune response or to interact with immunotherapy is still controversial. $^{39}$ Some studies have shown that multiple fractionation radiation is superior to single dose radiation, while other studies have reported similar results for both, or multiple fractionation radiation is inferior. Tsai et $\mathrm{al}^{40}$ reported selective up-regulation of IFN-related genes by fractionated dose $(2 \mathrm{~Gy} \times 5)$ but not single dose $(10 \mathrm{~Gy} \times 1)$ in human breast, prostate, and glioma tumor cells. Consistent with this, John-Aryankalayil et $\mathrm{al}^{41}$ showed that genes regulating immune and stress response, cell cycle, and apoptosis were significantly up-regulated by multi-fractionated radiation $(2 \mathrm{~Gy} \times 5)$ compared to single dose $(10 \mathrm{~Gy} \times 1)$ in human prostate cancer cells. Besides, a preclinical study of breast carcinoma cells receiving both ipilimumab and radiotherapy found that compared with a single dose ( $20 \mathrm{~Gy} \times 1)$, fractionated dose $(8 \mathrm{~Gy} \times 3$ or $6 \mathrm{~Gy} \times 5)$ resulted in upregulation of tumor-specific T-cells, leading to significant responses in both primary tumor and the tumors outside the radiation field. ${ }^{34}$ Conversely, Lugade et $\mathrm{a}^{42}$ found that single dose $(15 \mathrm{~Gy} \times 1)$ results in great numbers of immune cells than fractionated dose $(5 \mathrm{~Gy} \times 3)$ in mice with B16 melanoma tumors. However, Lee et $\mathrm{al}^{35}$ found comparable progressive growth of B16 melanoma tumors irrespective of being treated with single dose $(20 \mathrm{~Gy} \times 1)$ or fractionated dose (5 $\mathrm{Gy} \times 4$ ). This variability may be caused by a variety of different radiation technologies and energies, each with different scattering and dosimetry. In addition, the effects of fractionation could depend on the type of tumor or model system used. Therefore, further dose/fractionation comparison trials are needed to determine the optimal radiotherapy regimen.

\section{Sequencing}

Different from dose/fractionation, there is a relative consistency in preclinical studies on the sequence of immunotherapy and radiotherapy, and various studies have shown that simultaneous radiotherapy and immunotherapy are better than sequential therapy. Dewan et $\mathrm{al}^{34}$ showed that delaying the administration of anti-CTLA-4 antibody after radiation reduced the therapeutic effect. Dovedi et al ${ }^{36}$ found that the tumor cells of mice with colon cancer can be induced to express PD-L1 by the radiation dose of $10 \mathrm{~Gy}$ directly. If anti-PD-L1 antibody is used at the same time, rather than after radiation, the survival rate of mice can be improved. Mechanistically, the optimum time of immunotherapy and radiation-induced cell death, antigen presentation, transport, and T-cell engagement may depend on the type of immunotherapy used. Meanwhile, the efficacy of immunotherapy alone before radiotherapy may be limited due to the reduction of inflammatory cell death and the reduction of antigen targets of the immune system. ${ }^{43}$ 
Young et $\mathrm{al}^{44}$ compared the efficacy of anti-OX40 (a costimulatory signal for T-cell activation) and antiCTLA4 with 20 Gy in a single fraction in mice with colorectal cancer. It was found that radiotherapy and antiOX40 had the best survival rate if immunotherapy was carried out 1 day after radiotherapy, while radiotherapy and anti-CTLA4 had the best survival rate if immunotherapy was carried out 7 days before radiotherapy. This indicates that perhaps the specific mechanism of each immunotherapy may play a role in the optimal timing. ${ }^{44}$ To sum up, the current preclinical data support the concurrent administration of immunotherapy with radiotherapy but need further clinical data to confirm.

\section{Toxicities}

Due to the potential toxicities of radiotherapy combined with immunotherapy, caution should be exercised when combining these two therapies. In addition to complications of conventional radiotherapy, such as nausea, fatigue, skin damage, and hemopenia, the combination of radiotherapy and immunotherapy could put patients at risk of serious complications. Furthermore, immune side-effects associated with specific sites might increase, such as immunotherapy combined with lung irradiation, resulting in an increase in pneumonia, the same as liver irradiation resulting in hepatitis. A recent phase I trial of pembrolizumab and hypofractionated radiation therapy in bladder cancer reported a high risk for severe toxicity. In this study, patients received pembrolizumab and urinary bladder radiation to a dose of 36 Gy in 6 fractions. ${ }^{45}$ The trial was suspended after dose-limiting toxicity was observed in 5 patients. Three patients experienced grade 3 urinary toxicities and one patient experienced grade 4 intestinal perforation. However, Kwon et $\mathrm{al}^{46}$ reported no significant increase in intestinal toxicity when ipilimumab was combined with pelvic radiation, which suggested that immunotherapy could also be safely combined with radiotherapy to specific sites. Therefore, more clinical trials are needed to assess the risks and toxicity of radiotherapy combined with immunotherapy.

\section{Conclusion}

Immunotherapy has produced substantial and enduring clinical responses in a series of studies and is becoming the fourth backbone of cancer treatment after surgery, chemotherapy, and radiotherapy. In addition, a series of published studies have shown that radiation enhances many steps required to generate an antigen-specific immune response, including tumor cell death, antigen cross-presentation, and cytotoxic $\mathrm{T}$ cell activation and proliferation. The combination of immunotherapy and radiotherapy can lead to local and systemic enduring responses of urological malignancies, which have been confirmed by increasing preclinical and clinical evidence. However, there are still many outstanding questions and trials in progress, which are expected to clarify appropriate patient selection and practical considerations, such as dose/fractionation, sequencing for delivery of therapy, and treatment-related toxicity, to maximize the treatment effect. Furthermore, whether other systemic therapies such as neoadjuvant chemotherapy can enhance the synergistic effect of radiotherapy and immunotherapy also provides more ideas and possible options for urological malignancy treatment in the future.

\section{Disclosure}

The authors report no conflicts of interest in this work.

\section{References}

1. Order SE. The effects of therapeutic irradiation on lymphocytes and immunity. Cancer. 1977;39(S2):737-743.

2. Jacob VD. The Modern Technology of Radiation Oncology. Madison, WI: Medical Physics Publishing; 2013.

3. Hall EJ, Giaccia AJ. Radiobiology for the Radiologist. 6th ed. Philadelphia: Lippincott Williams \& Wilkins; 2006.

4. Stone HB, Peters LJ, Milas L. Effect of host immune capability on radiocurability and subsequent transplantability of a murine fibrosarcoma. J Natl Cancer Inst. 1979;63(5):1229-1235.

5. Demaria S, Golden EB, Formenti SC. Role of local radiation therapy in cancer immunotherapy. JAMA Oncol. 2015;1(9):1325-1332. doi:10.1001/jamaoncol.2015.2756

6. Formenti SC, Demaria S. Systemic effects of local radiotherapy. Lancet Oncol. 2009;10(7):718-726. doi:10.1016/S1470-2045(09) 70082-8

7. Salama AK, Postow MA, Salama JK. Irradiation and immunotherapy: from concept to the clinic. Cancer. 2016;122(11):1659-1671. doi:10.1002/cncr.29889

8. Park B, Yee C, Lee KM. The effect of radiation on the immune response to cancers. Int J Mol Sci. 2014;15(1):927-943. doi:10.3390/ ijms 15010927

9. Brooks ED, Schoenhals JE, Tang C, et al. Stereotactic ablative radiation therapy combined with immunotherapy for solid tumors. Cancer J. 2016;22(4):257-266. doi:10.1097/PPO.0000000000000210

10. Formenti SC, Demaria S. Combining radiotherapy and cancer immunotherapy: a paradigm shift. $J$ Natl Cancer Inst. 2013;105 (4):256-265. doi:10.1093/jnci/djs629

11. Weichselbaum RR, Liang H, Deng L, Fu Y-X. Radiotherapy and immunotherapy: a beneficial liaison? Nat Rev Clin Oncol. 2017;14 (6):365-379

12. Shabason JE, Minn AJ. Radiation and immune checkpoint blockade: from bench to clinic. Semin Radiat Oncol. 2017;27(3):289-298. doi:10.1016/j.semradonc.2017.03.002

13. Kroemer G, Galluzzi L, Kepp O, Zitvogel L. Immunogenic cell death in cancer therapy. Annu Rev Immunol. 2013;31:51-72. doi:10.1146/ annurev-immunol-032712-100008 
14. Akashi M, Hachiya M, Koeffler HP, Suzuki G. Irradiation increases levels of GM-CSF through RNA stabilization which requires an AU-rich region in cancer cells. Biochem Biophys Res Commun. 1992;189(2):986-993. doi:10.1016/0006-291X(92)92301-D

15. Demaria S, Pilones KA, Vanpouille-Box C, Golden EB, Formenti SC. The optimal partnership of radiation and immunotherapy: from preclinical studies to clinical translation. Radiat Res. 2014;182 (2):170-181. doi:10.1667/RR13500.1

16. Gameiro SR, Jammeh ML, Wattenberg MM, Tsang KY, Ferrone S, Hodge JW. Radiation-induced immunogenic modulation of tumor enhances antigen processing and calreticulin exposure, resulting in enhanced T-cell killing. Oncotarget. 2014;5(2):403-416. doi:10.18632/oncotarget.1719

17. Rovere-Querini P, Capobianco A, Scaffidi P, et al. HMGB1 is an endogenous immune adjuvant released by necrotic cells. EMBO Rep. 2004;5(8):825-830. doi:10.1038/sj.embor.7400205

18. Ganss R, Ryschich E, Klar E, Arnold B, Hämmerling GJ. Combination of T-cell therapy and trigger of inflammation induces remodeling of the vasculature and tumor eradication. $J$ Cancer Research. 2002;62(5):1462-1470.

19. Matsumura S, Wang B, Kawashima N, et al. Radiation-induced CXCL16 release by breast cancer cells attracts effector $\mathrm{T}$ cells. J Immunol. 2008;181(5):3099-3107. doi:10.4049/jimmunol.181.5.3099

20. Shahabi V, Postow MA, Tuck D, Wolchok JD. Immune-priming of the tumor microenvironment by radiotherapy: rationale for combination with immunotherapy to improve anticancer efficacy. Am J Clin Oncol. 2015;38(1):90-97. doi:10.1097/COC.0b013e3182868ec8

21. Chakraborty M, Abrams SI, Coleman CN, Camphausen K, Hodge JWJCR. External beam radiation of tumors alters phenotype of tumor cells to render them susceptible to vaccine-mediated T-cell killing. Cancer Res. 2004;64(12):4328-4337. doi:10.1158/00085472.CAN-04-0073

22. Chakraborty M, Abrams SI, Camphausen K, et al. Irradiation of tumor cells up-regulates fas and enhances CTL lytic activity and CTL adoptive immunotherapy. J Immunol. 2003;170 (12):6338-6347. doi:10.4049/jimmunol.170.12.6338

23. Garnett CT, Palena C, Chakraborty M, Tsang K-Y, Schlom J, Hodge JW. Sublethal irradiation of human tumor cells modulates phenotype resulting in enhanced killing by cytotoxic $\mathrm{T}$ lymphocytes. Cancer Res. 2004;64(21):7985-7994. doi:10.1158/ 0008-5472.CAN-04-1525

24. Sharabi AB, Nirschl CJ, Kochel CM, et al. Stereotactic radiation therapy augments antigen-specific PD-1-mediated antitumor immune responses via cross-presentation of tumor antigen. J Cancer Immunol Res. 2016;3(4):345-355. doi:10.1158/2326-6066.CIR-14-0196

25. Kachikwu EL, Iwamoto KS, Liao YP, et al. Radiation enhances regulatory $\mathrm{T}$ cell representation. Int $J$ Radiat Oncol Biol Phys. 2011;81(4):1128-1135. doi:10.1016/j.ijrobp.2010.09.034

26. Kumar V, Patel S, Tcyganov E, Gabrilovich DI. The nature of myeloid-derived suppressor cells in the tumor microenvironment. J Trends Immunol. 2016;37(3):208-220. doi:10.1016/j.it.2016.01.004

27. Wu CT, Chen WC, Chang YH, Lin WY, Chen MF. The role of PD-L1 in the radiation response and clinical outcome for bladder cancer. $S c i$ Rep. 2016;6:19740. doi:10.1038/srep19740

28. Persa E, Balogh A, Safrany G, Lumniczky K. The effect of ionizing radiation on regulatory $\mathrm{T}$ cells in health and disease. Cancer Lett. 2015;368(2):252-261. doi:10.1016/j.canlet.2015.03.003

29. Twyman-Saint Victor C, Rech AJ, Maity A, et al. Radiation and dual checkpoint blockade activate non-redundant immune mechanisms in cancer. Nature. 2015;520(7547):373-377. doi:10.1038/ nature 14292

30. Mole RH. Whole body irradiation-radiobiology or medicine? $\mathrm{Br}$ J Radiol. 1953;26(305):234-241. doi:10.1259/0007-1285-26-305-234

31. Abuodeh Y, Venkat P, Kim S. Systematic review of case reports on the abscopal effect. Curr Probl Cancer. 2016;40(1):25-37. doi:10.1016/j.currproblcancer.2015.10.001
32. Golden EB, Chhabra A, Chachoua A, et al. Local radiotherapy and granulocyte-macrophage colony-stimulating factor to generate abscopal responses in patients with metastatic solid tumours: a proof-ofprinciple trial. Lancet Oncol. 2015;16(7):795-803. doi:10.1016/ S1470-2045(15)00054-6

33. Park SS, Dong H, Liu X, et al. PD-1 Restrains radiotherapy-induced abscopal effect. Cancer Immunol Res. 2015;3(6):610-619. doi:10.1158/2326-6066.CIR-14-0138

34. Dewan MZ, Galloway AE, Kawashima N, et al. Fractionated but not single-dose radiotherapy induces an immune-mediated abscopal effect when combined with anti-CTLA-4 antibody. Clin Cancer Res. 2009;15(17):5379-5388. doi:10.1158/1078-0432. CCR-09-0265

35. Lee Y, Auh SL, Wang Y, et al. Therapeutic effects of ablative radiation on local tumor require $\mathrm{CD} 8+\mathrm{T}$ cells: changing strategies for cancer treatment. Blood. 2009;114(3):589-595. doi:10.1182/ blood-2009-02-206870

36. Dovedi SJ, Adlard AL, Lipowska-Bhalla G, et al. Acquired resistance to fractionated radiotherapy can be overcome by concurrent PD-L1 blockade. Cancer Res. 2014;74(19):5458-5468. doi:10.1158/00085472.CAN-14-1258

37. Kantoff PW, Higano CS, Shore ND, et al. Sipuleucel-T immunotherapy for castration-resistant prostate cancer. $N$ Engl J Med. 2010;363 (5):411-422. doi:10.1056/NEJMoa1001294

38. Hoos A, Ibrahim R, Korman A, et al. Development of ipilimumab: contribution to a new paradigm for cancer immunotherapy. Semin Oncol. 2010;37(5):533-546. doi:10.1053/j.seminoncol.2010.09.015

39. Demaria S, Formenti SC. Radiation as an immunological adjuvant: current evidence on dose and fractionation. Front Oncol. 2012;2:153. doi:10.3389/fonc. 2012.00153

40. Tsai MH, Cook JA, Chandramouli GV, et al. Gene expression profiling of breast, prostate, and glioma cells following single versus fractionated doses of radiation. Cancer Res. 2007;67(8):3845-3852. doi:10.1158/0008-5472.CAN-06-4250

41. John-Aryankalayil M, Palayoor ST, Cerna D, et al. Fractionated radiation therapy can induce a molecular profile for therapeutic targeting. Radiat Res. 2010;174(4):446-458. doi:10.1667/RR2105.1

42. Lugade AA, Moran JP, Gerber SA, Rose RC, Frelinger JG, Lord EM. Local radiation therapy of B16 melanoma tumors increases the generation of tumor antigen-specific effector cells that traffic to the tumor. Jimmunol. 2005;174(12):7516-7523. doi:10.4049/jimmunol.174.12.7516

43. Sharabi AB, Lim M, DeWeese TL, Drake CG. Radiation and checkpoint blockade immunotherapy: radiosensitisation and potential mechanisms of synergy. Lancet Oncol. 2015;16(13):e498-e509. doi:10.1016/S1470-2045(15)00007-8

44. Young KH, Baird JR, Savage T, et al. Optimizing timing of immunotherapy improves control of tumors by hypofractionated radiation therapy. PLoS One. 2016;11(6):e0157164. doi:10.1371/journal.pone.0157164

45. Tree AC, Jones K, Hafeez S, et al. Dose-limiting urinary toxicity with pembrolizumab combined with weekly hypofractionated radiation therapy in bladder cancer. Int J Radiat Oncol Biol Phys. 2018;101 (5):1168-1171. doi:10.1016/j.ijrobp.2018.04.070

46. Kwon ED, Drake CG, Scher HI, et al. Ipilimumab versus placebo after radiotherapy in patients with metastatic castration-resistant prostate cancer that had progressed after docetaxel chemotherapy (CA184-043): a multicentre, randomised, double-blind, Phase 3 trial. Lancet Oncol. 2014;15(7):700-712. doi:10.1016/S1470-2045(14)70189-5

47. Cristina M, Cinzia I, Ugo DG, et al. Nivolumab (NIVO) in combination with stereotactic body radiotherapy (SBRT) in pretreated patients (pts) with metastatic renal cell carcinoma (mRCC): first results of phase II NIVES study. J Clin Oncol. 2020;38(abstr):613. doi:10.1200/JCO.2020.38.6_suppl.613

48. Hans H, Dendra VM, Chul A, et al. Combination of dual immune checkpoint inhibition (ICI) with stereotactic radiation (SBRT) in metastatic renal cell carcinoma (mRCC)(RADVAX RCC). J Clin Oncol. 2020;38(abstr):614. doi:10.1200/JCO.2020.38.6_suppl.614 


\section{Publish your work in this journal}

Cancer Management and Research is an international, peer-reviewed open access journal focusing on cancer research and the optimal use of preventative and integrated treatment interventions to achieve improved outcomes, enhanced survival and quality of life for the cancer patient.

Submit your manuscript here: https://www.dovepress.com/cancer-management-and-research-journal
The manuscript management system is completely online and includes a very quick and fair peer-review system, which is all easy to use. Visit http://www.dovepress.com/testimonials.php to read real quotes from published authors. 